DOI: http://dx.doi.org/10.33846/hn40502

http://heanoti.com/index.php/hn

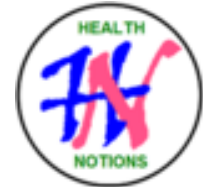

RESEARCH ARTICLE

URL of this article: http://heanoti.com/index.php/hn/article/view/hn40502

\title{
Identification of the Anthelmintic Power of Anting-anting Leaf and Starfruit Leaf
}

\author{
Sri Sulami Endah Astuti ${ }^{1(\mathrm{CA})}$ \\ ${ }^{1(\mathrm{CA})}$ Medical Laboratory Department, Poltekkes Kemenkes Surabaya; srisulamiea@ gmail.com (Corresponding \\ Author)
}

\begin{abstract}
Ascariasis is an intestinal infection caused by the parasitic worm Ascaris lumbricoides. Starfruit leaf (Averrhoa bilimbi) and leaf anting-anting (Acalypha indica L) is a plant that is often used as a worm remedy in the community. Starfruit leaves (Averrhoa bilimbi) and Leaf anting-anting (Acalypha indica L) contain several compounds that have the potential as anthelmintics, namely saponins, tannins and flavonoids. The purpose of this study was to determine the effect of ethanol extention of starfruit leaf leaves (Averrhoa bilimbi) and leaf anting-anting (Acalypha indica L) as anthelmintic on the time of death of Ascaris suum Goeze worms in vitro. The method in this study is experimental with post test only group design. Test animals from the study are Ascaris suum. The study was conducted at the Parasitology Laboratory, Medical Laboratory Department, Poltekkes Kemenkes Surabaya in 2019. This study used 6 treatment groups, $\mathrm{NaCl} 0.9 \%$ as a negative control and pirantel pamoate $0.25 \%$ as a positive control and ethanol extract of wuluh starfruit leaf and ethanol extract of Anting-anting with concentrations of leaves. 40\%, 60\%, 80\% and 100\%. Data were analyzed using the Kolmogrov-Smirnov test, the Anova two way Block Design test, then continued using the Post Hoc test to determine differences between blocks and between treatments, against the time of Ascaris suum worm's death. The average time of death of Ascaris suum caused by ethanol extract of starfruit leaves concentration of $40 \%$ for 492.3 minutes and ethanol extract of leaf anting-anting 396.5 minutes, concentration of $60 \%$ ethanol extract of wuluh starfruit leaves for 278.5 minutes and leaf extract ethanol leaf anting-anting for 283.5 minutes, $80 \%$ concentration of ethanol extract of wuluh starfruit leaf for 141.8 minutes and ethanol extract of anting-anting leaf for 174 minutes, $100 \%$ concentration of ethanol extract of wuluh starfruit leaves for 66.75 minutes and extract ethanol leaf anting-anting for 92 minutes. So it can be concluded that the ethanol extract of starfruit leaves has an anthelmintic effect on the Ascaris suum worm more optimum than the ethanol extract of the Anting-anting leaves, because the time required is close to positive control that is 60 minutes.
\end{abstract}

Keywords: anthelmintic; Ascaris suum; starfruit leaf; anting-anting leaf

\section{INTRODUCTION}

Ascariasis is a worm disease that often occurs in tropical and developing countries. ${ }^{(1)}$. Worming is a disease that is based on the environment. This can be influenced by tropical climate and high humidity. Indonesia is a good environment for worm development, as well as sanitation and hygiene conditions that do not meet health requirements and inadequate socio-economic conditions and education. ${ }^{(2)}$ This state of helminthiasis can result in decreased health, nutrition, intelligence, and productivity of sufferers. ${ }^{(3)}$

In 2015, the prevalence of ascariasis in the world was 807 million, while in Southeast Asia it was 589 million. Indonesia has an average prevalence of ascariasis in 33 provinces in 2012 of $31.8 \%$ with the highest percentage occurring at school age. ${ }^{(4)}$ This is influenced by several factors, such as individual hygiene, environmental sanitation, and maternal knowledge. ${ }^{(5)}$

Ascariasis is an infection caused by Ascaris lumbricoides or roundworms. ${ }^{(6)}$ Adult worm predilection is found in the lumen of the human small intestine, but is sometimes found in other parts of the intestine. ${ }^{(7)}$ Early ascariasis infection is characterized by worms coming out with feces or worms coming out of the mouth, nose 
and anus. ${ }^{(8)}$ Worm infections can cause a decrease in nutrients and blood loss. ${ }^{(9)}$ These worms can also cause intestinal obstruction, reduced appetite, diarrhea, constipation, and impaired child development. ${ }^{(1)}$

Ascariasis can be treated using worm medicine. Worm medicine which is the choice of ascariasis is pirantel pamoat which is a single dose drug and is the first line in the treatment of worm infections. However, these drugs have side effects in the form of digestive disorders such as abdominal pain and diarrhea. Some deficiencies in the anthelmintic drugs above are relatively expensive. So we need to find other alternatives that can suppress the prevention of ascariasis with natural ingredients that are easily available. ${ }^{(6)}$

Traditional medicines contain many chemicals that have anthelmintic effects, among these chemicals are flavonoids, tannins, and saponins. One of the plants in Indonesia that contains flavonoid compounds, tannins, and saponins is starfruit (Averrhoa bilimbi Linn) and leaf anting-anting (Acalypha indica L). As has been found from previous studies. ${ }^{(10)}$ that the results of photochemical screening show that simplicia from starfruit leaves contain flavonoids, saponins, tannins and steroids / triterpenoids.

Ascaris suum Goeze test animals are used as research subjects, because Ascaris lumbricoides Linn as an obligate parasite in humans cannot be found living outside the human body. Ascaris suum Goeze is a roundworm found in the pig's small intestine. ${ }^{(4)}$ Although genetically different, judging by its morphological characteristics, Ascaris lumbricoides (L) has many similarities with Ascaris suum Goeze, as well as several traits such as the way of life and breeding, worms of this genus are the same. ${ }^{(11)}$

\section{METHODS}

\section{Types of Study}

This type of study was an experimental research in order to determine the effect of ethanol extract of starfruit leaf (Averrhoa bilimbi) and anting-anting leaf (Acalypha indica L) as anthelmintic on the time of death of Ascaris suum, Goeze roundworm in vitro by using a post test only with control group design.

\section{Material}

The materials used in this study were starfruit leaves (Averrhoa bilimbi) and anting-anting leaves (Acalypha indica L) obtained from the UPT Materia Medika, in Pesanggrahan Village, Batu sub-district, Batu, East Java, Indonesia.

\section{Animals}

The test animal used was Ascaris suum, adult Goeze has a length of $30-35 \mathrm{~cm}$ that is still actively obtained from the intestine of pigs from the slaughterhouse on Jl. Pegirian Surabaya, East Java, Indonesia.

\section{Location and Time}

The study was conducted in the Parasitology Laboratory, Medical Laboratory Department, Poltekkes Kemenkes Surabaya and at the Faculty of Veterinary Medicine, Universitas Airlangga in 2019.

\section{Sampling}

This study used a purposive sampling technique by equalizing the length of the worm and the type of worm and did not differentiate the sex of the worm. Worm samples used in this study were five animals per treatment. Determination of the number of research replications was carried out using the Frederer formula.

\section{Data Collection Method}

This study used observational data collection techniques (direct observation) by observing the time of death of Ascaris suum worm after giving ethanol extract of starfruit leaf (Averrhoa bilimbi) and ethanol extract of anting-anting leaves (Acalypha indica L) with a concentration of 40\%,60\%,80\% and 100\%. Negative control was carried out to determine the quality of the Ascaris suum worm sample used in this study. 
Making Simplisia Wuluh Starfruit Leaves (Averrhoa bilimbi, L) and Anting-anting Leaves (Acalypha indica, $\mathbf{L})$

Washing the leaves of starfruit and leaves of anting-anting using running water, drain, then dried by aerating (without sunlight) to dry completely. Smooth the dried wuluh starfruit leaves and anting-anting leaves using mortar and pestle and then the sifting of the starfruit leaves and the leaves of the anting-anting have dried to get the starfruit leaf powder and anting-anting powder.

Making Ethanol Extract of Wuluh Starfruit Leaves (Averrhoa bilimbi, L) and Anting-anting leaves (Acalypha indica L)

Weigh the dried starfruit leaf powder as much as 1000 grams then put it into a maceration container and perform the extraction process using maceration method with $96 \%$ ethanol solvent.

Soak the dried starfruit leaf powder using $96 \%$ ethanol, covered with aluminum foil and left for $3 \times 24$ hours at room temperature. After $3 \times 24$ hours, the sample soaked with $96 \%$ ethanol was filtered using filter paper. Maserat results were collected and concentrated using a rotatory vacum evaporator at a temperature of $50^{\circ} \mathrm{C}$ until a concentrated extract was obtained. Leave the concentrated extracts produced at room temperature until all the ethanol solvents evaporate. Concentrated ethanol extract of starfruit leaves (Averrhoa bilimbi) $100 \%$. Likewise for anting-anting - branches done the same thing as in the leaves of wuluh starfruit.

\section{Positive Control Making (Pirantel Pamoat 0.25\%)}

Dissolve $250 \mathrm{mg}$ of Pirantel Pamoat with $100 \mathrm{ml}$ of distilled water.

\section{Negative Control Making ( $\mathrm{NaCl} 0.9 \%)$}

Dissolve 0.9 grams of $\mathrm{NaCl}$ in $100 \mathrm{ml}$ of distilled water.

\section{Making Ethanol Extract of Wuluh Starfruit Leaves and Anting-anting Leaves (Acalypha indica L)} Concentration of $\mathbf{4 0 \%}$

Dissolve 8 grams of concentrated extract of ethanol starfruit leaves with $0.1 \mathrm{~mL}$ of Tween 80 surfactant solution and then add $20 \mathrm{~mL}$ of $0.9 \% \mathrm{NaCl}$ slowly. The same thing was done for Anting-anting leaves.

\section{Making Ethanol Extract of Wuluh Starfruit Leaves and Anting-anting Leaves (Acalypha indica L)} Concentration of $60 \%$

Dissolve 12 grams of concentrated extract of ethanol starfruit leaves with $0.1 \mathrm{~mL}$ of Tween 80 surfactant solution and then add $20 \mathrm{~mL}$ of $0.9 \% \mathrm{NaCl}$ slowly. The same thing was done for anting-anting leaves.

Making Ethanol Extract of Wuluh Starfruit Leaves and Anting-anting Leaves (Acalypha indica L) Concentration of $80 \%$

Dissolve 16 grams of concentrated extract of ethanol starfruit leaves with $0.1 \mathrm{~mL}$ of Tween 80 Surfactant solution and then add $20 \mathrm{~mL}$ of $0.9 \% \mathrm{NaCl}$ slowly. The same thing was done for Anting-anting leaves.

Making Ethanol Extract of Wuluh Starfruit Leaves and Anting-anting Leaves (Acalypha indica L) Concentration of $\mathbf{1 0 0 \%}$

Made using thick extract without dilution. The same thing was done for leaf anting-anting. 


\section{Observation of the Anthelmintic Effect of Wuluh Starfruit Leaf Extract and Anting-anting Leaf (Acalypha indica $\mathbf{L}$ )}

Prepare a test container to be used for observing the anthelmintic power. Fill each test container with a solution of ethanol extract of starfruit leaf (Averrhoa bilimbi) with 40\%, 60\%, 80\%, and 100\% constructions, negative control, and positive control. The negative control contained $0.9 \% \mathrm{NaCl}$ solution. The positive control contained a $0.25 \%$ pirantel pamoate solution.

Add five Ascaris suum worms to each petri dish which contains a solution of ethanol extract of starfruit leaf (Averrhoa bilimbi), negative control solution and positive control solution. Observe the movements of Ascaris suum worms every minute by touching the body of Ascaris suum worms using anatomical tweezers. Record the number of worms that died and the time of death Ascaris suum worms. The same was done for the same thing with anting-anting leaf ethanol extract solution.

\section{Data Analysis Techniques}

Quantitative data analysis techniques were taken from primary data that was data obtained from observations of the number of Ascaris suum worm deaths and the time of Ascaris suum worm deaths after being treated with ethanol extract of wuluh starfruit leaf (Averrhoa bilimbi) and ethanol extract of anting-anting leaves (Acalypha indica indica) 1) will then be presented using tables and graphs. The data obtained will be analyzed using the Kolmogrov-Smirnov statistical test to determine the normality of the data obtained and proceed with the homogeneity test using the SPSS application. Anova Two Way test was then performed to determine differences between blocks and between treatments.

\section{RESULTS}

\section{Data Presentation}

Table 1. The results of research on the effect of giving wuluh starfruit leaf ethanol extract as anthelmintic against the time of death of Ascaris suum, Goeze by In Vitro (minutes)

\begin{tabular}{|c|c|c|c|c|c|c|}
\hline \multirow[t]{2}{*}{ Replication } & \multicolumn{4}{|c|}{ Time of death Ascaris suum Goeze (minute) } & \multicolumn{2}{|c|}{ Control } \\
\hline & $40 \%$ & $60 \%$ & $80 \%$ & $100 \%$ & + & - \\
\hline 1 & 488 & 266 & 118.25 & 62 & 60 & 5760 \\
\hline 2 & 482.5 & 297.25 & 147 & 71.5 & 60 & 5760 \\
\hline 3 & 497 & 285 & 154.5 & 68 & 60 & 5760 \\
\hline 4 & 501.25 & 286.5 & 148.75 & 64.5 & 60 & 5760 \\
\hline Mean & 492.875 & 282.5625 & 142.25 & 66.75 & 60 & 5765 \\
\hline
\end{tabular}

Figure 1 illustrates the acceleration of the death of the Ascaris suum worm. This is shown by the decrease in the graph caused by the ethanol extract of starfruit leaves with concentration of $40 \%$ to ethanol extract of starfruit leaves with concentration of $100 \%$ and ethanol extract of anting-anting leaves with concentration of $40 \%$ to $100 \%$ concentration. 


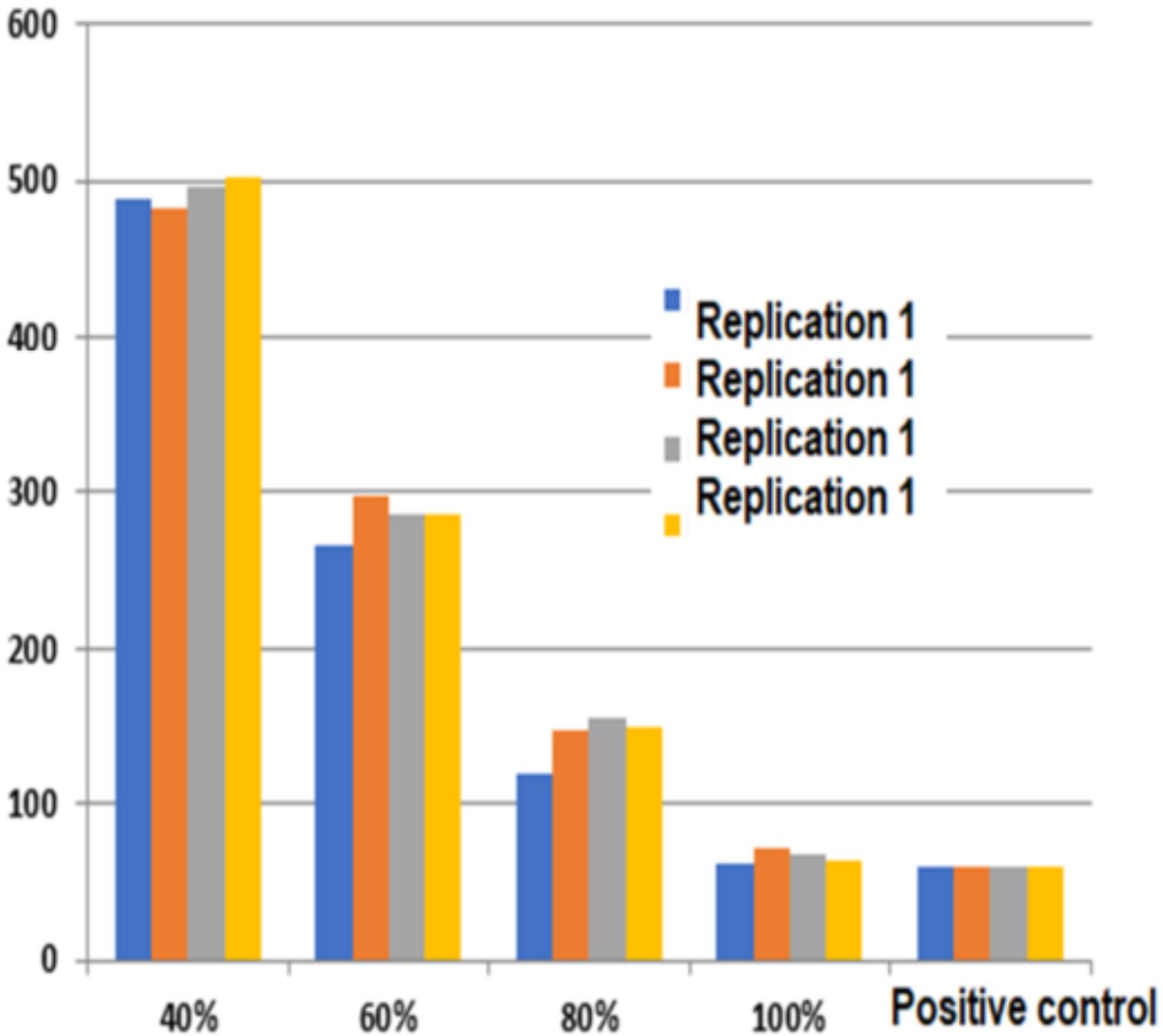

Figure 1. Time of the death of Ascaris suum worm caused by ethanol extract of starfruit leaf and ethanol extract of anting-anting leaf (in minutes)

\section{Data Analysis}

To find out the significant influence of worm death time from ethanol extracts of starfruit leaf leaves and anting-anting leaf ethanol extracts in the four concentration groups, a data normality test was first performed to find out whether the data was normally distributed or not and the homogeneity test of the data to find out the data homogeneous or not. If the data is normally distributed and homogeneous then the Two Way Anova parametric test is continued while if the data is not normally distributed and is not homogeneous then the Kruskal-Wallis non parametric test is continued. From the data and research results regarding the effect of ethanol extract of starfruit leaf (Averrhoa bilimbi) and ethanol extract of anting-anting leaf (Acalypha indica $\mathrm{L}$ ) as anthelmintic on the time of death of Ascaris suum worm, Goeze in vitro will be statistically tested using Parametric test because normal distributed data, namely the two way Anova test.

Based on the results of statistical tests with the two way Anova for inter-block analysis produced pvalues of 0.697 , meaning that there was no difference between the blocks. The conclusions of anting-anting leaf extract and wuluh fruitstar leaf extract had the same function as pirantel pamoat as antelmintic. The results of the inter-treatment analysis obtained p-value of 0.002, meaning there were differences between treatments.

To find out the pairs of different treatment groups, a multiple comparison test was conducted using the Post-Hoc Test. The results of the multiple comparison test with the Post Hoc Test of ethanol extract of starfruit leaf leaves and ethanol extract of anting-anting leaves concentration of $40 \%$ had different values with ethanol extract of starfruit leaf leaves and ethanol extract of anting-anting leaves concentration of $60 \%$, concentration of $80 \%$, concentration of $100 \%$, negative control and positive control.

The results of the multiple comparison test with the Post Hoc Test of ethanol extract of starfruit leaf leaves and ethanol extract of anting-anting leaves concentration of $40 \%$ had different values with ethanol extract of starfruit leaf leaves and ethanol extract of anting-anting leaves concentration of $60 \%$, concentration of $80 \%$, concentration of $100 \%$ negative control and positive control. 
At concentrations of $80 \%$ and $100 \%$ ethanol extract of wuluh starfruit leaf and ethanol extract of antinganting leaves did not differ from positive control namely pirantel pamoat. The $80 \%$ concentration and $100 \%$ concentration had the opportunity to be developed as an anthelmintic drug, especially in ascariasis, because it did not have a significant difference with positive control.

\section{DISCUSSION}

Based on the results of the study, it can be seen that the average death time of Ascaris suum worm on starfruit leaf extract and anting-anting leaves concentration of $40 \%$ is 492.3 and 396.5 minutes, at a concentration of $60 \%$, the average time of death is 278,5 and 283.5 minutes, at a concentration of $80 \%$, the mean time of death was 141.8 and 174 minutes, and at a concentration of $100 \%$, the mean time of death was 66.75 and 92 minutes. This shows that there was an acceleration of the death of Ascaris suum worm by increasing the concentration of ethanol extract of starfruit leaf and ethanol extract of the leaf of anting-anting, meaning that ethanol extract of starfruit leaf and ethanol extract of anting-anting leaf had anthelmintic effect by showing the faster time of death of worms on the higher concentration of ethanol extract of starfruit leaves was $100 \%$.

Meanwhile, for the positive control used in this study is Pirantel Pamoat which is one of the standard drugs for ascariasis. Researchers used pirental pamoate with a concentration of $0.25 \%$ which is equivalent to the dose of one-time tablet that is as much as $250 \mathrm{mg}$ per tablet.

This positive control can cause the death of Ascaris suum worms with an average of 60 minutes. This is because the pyrantel pamoate can inhibit the process of neuromuscular depolarization in the worm's body, so that it can cause spastic neuromuscular paralysis and worm death. In addition, it also inhibits the enzyme cholinesterase thereby increasing muscle contraction in the worm's body ${ }^{(7)}$. Pirantel pamoat used is tabletshaped, so to get a concentration of $0.25 \%$, a $100 \mathrm{~mL}$ aquadest solution is used.

The Pos-Hoc Test results show that there are significant differences between the treatment groups (concentrations) of ethanol extracts of starfruit leaf leaves and ethanol of extract of anting-anting leaf. Based on the results of these studies indicate that the ethanol extract of starfruit leaf and ethanol extract of anting-anting leaves have anthelmintic power, because there is an acceleration of the time of death of the Ascaris suum worm, Goeze. At the highest concentration of ethanol extract of starfruit leaves, $100 \%$.

The anthelmintic effect that comes from starfruit leaves and anting-anting leaves due to the presence of active substances saponins, tannins and flavonoids that act as anthelmintics as has been found from previous studies by Masduqi \& Anggoro ${ }^{(12)}$ that the results of phytochemical screening, wuluh starfruit leaf extracts contains compounds including: alkaloids, flavonoids, tannins, saponins and triterpenoids.

According to a quote from Kristianto ${ }^{(13)}$ states that the content of saponins contained in starfruit leaves is $10.0 \%$, and the content of tannins contained in starfruit leaves) as much as $6.0 \%$. Whereas in previous studies Ramadan, et al. ${ }^{(14)}$ stated that the content of flavonoids in starfruit leaf extract with $96 \%$ ethanol solvent amounted to $2.265 \%$.

Saponin compounds contained in extracts of starfruit leaf leaves and leaf anting-anting are compounds in the form of glycosides. The mechanism of saponin compounds as anthelmintic is that it has the potential to kill worms because it works by inhibiting the enzyme acetylcholinesterase and irritating the mucous membrane, so that the worm will experience muscle paralysis and lead to death ${ }^{(2)}$.

While the mechanism of action possessed by tannins is by interfering with the negative ion charge of the worm's body into positive ions (protonization) which then these positive ions attract the worm's body protein in the digestive tract so that it disrupts the metabolism and homeostasis of the worm's body. ${ }^{(6)}$

In addition to saponins and tannins there are flavonoid compounds that support the acceleration of worm death time. According to Ulya, et al. ${ }^{(7)}$ the ability of flavonoids in anthelmintics, namely flavonoids that come in direct contact with the worm's body, will be quickly absorbed into the worm's body and will cause denaturation of proteins in the tissues, causing death in the worms. Therefore, this research can produce an acceleration time of Ascaris suum worms followed by an increase in the concentration of ethanol extract of starfruit leaf leaves and anting-anting leaves.

Based on the results of the study in table 1 it can be concluded that the ethanol extract of starfruit leaves at a concentration of $100 \%$ has an influence on the time of death of Ascaris suum worms and can be used as an anthelmintic because it has a faster death time and is anting-anting the time of death caused by positive control, while the ethanol of extract of starfruit leaf and ethanol of extract of anting-anting leaves at concentrations of $40 \%, 60 \%$, and $80 \%$ have a death time that is far from positive control, so that it can still be used as an anthelmintic but is less than optimal.

Ethanol extract of starfruit leaves has a high chance to be developed as an anthelmintic drug, especially in askariasis. Because, there is an acceleration of the death of the Ascaris suum worm caused by ethanol extract of starfruit leaves. In addition, the use of Pirantel pamoate has side effects in the form of digestive disorders, 
fever and headaches, which may not be found in the use of ethanol extracts of starfruit leaves as a worm medicine $^{(15)}$.

\section{Conclussion}

The ethanol extract of starfruit leaf and ethanol extract of anting-anting leaf has an influence on the time of death of Ascaris suum, Goeze worms in vitro. This can be seen from the average time of death of the Ascaris suum, Goeze worm as follows:

The time of Ascaris suum worm death caused by ethanol extract of starfruit leaves concentration of $40 \%$ was 482.3 minutes and ethanol extract of anting-anting leaves concentration of $40 \%$ was 396.5 minutes. The time of death of Ascaris suum worm caused by ethanol extract starfruit leaves concentration $60 \%$ for 278.5 minutes and ethanol extract of anting-anting leaf leaves concentration $60 \%$ for 283.5 minutes. The time of death of Ascaris suum worm caused by ethanol extract of starfruit leaves $80 \%$ concentration was 141.8 minutes and ethanol extract of anting-anting leaves $80 \%$ concentration was 174 minutes. The time of death of Ascaris suum worm caused by ethanol extract of starfruit leaves $100 \%$ concentration was 66.75 minutes and ethanol extract of anting-anting leaves was $100 \%$ concentration that was for 92 minutes. The most optimum concentration in killing Ascaris suum worms, Goeze based on the time of A.suum worm death approaching positive control was starfruit leaf extract with $100 \%$ concentration for 66.75 minutes.

\section{Suggestion}

1. For the next researcher, it is expected to test the active compounds in the ethanol extract of leaves and starfruit, especially the active compounds which act as anthelmintics.

2. For the community can utilize the parts of the starfruit leaf plant to be used as an alternative treatment for Askariasis.

\section{REFERENCES}

1. Budiyanti RT. Anthelmintic effect of Sambiloto Herb Infusion (Efek Anthelmintik Infusa Herba Sambiloto). Surakarta: FK UNS; 2010.

2. Intannia D, et al. The Influence of Ethanol Extract and n-Hexane Extract of Chinese Ketepeng Leaves (Cassia Alata. L) on the Time of Death of Chicken Tapeworms (Raillietina Sp.) In Vitro (Pengaruh Pemberian Ekstrak Etanol dan Ekstrak n-Heksan Daun Ketepeng Cina (Cassia Alata. L) Terhadap Waktu Kematian Cacing Pita Ayam (Raillietina Sp.) Secara In Vitro). Jurnal Pharmascience. 2015;2(1).

3. MoH-RI. Decree of the Minister of Health of the Republic of Indonesia Number 424 of 2006 concerning Guidelines for Control of helminthiasis (Keputusan Menteri Kesehatan Republik Indonesia Nomor 424 Tahun 2006 Tentang Pedoman Pengendalian Kecacingan). Jakarta: MoH-RI; 2006.

4. Salam YA. The anthelmintic effect of ethanol extract of mahogany seeds (Swietenia mahagoni Jacq) on the death of Ascaris suum, Goeze in vitro (Efek Anthelmintik Ekstrak Etanol Biji Mahoni (Swietenia mahagoni Jacq) Terhadap Kematian Ascaris suum, Goeze Secara In Vitro). Surakarta: UNS; 2017.

5. Amelia M, Tjokopranoto R, Jasaputra KD. Effect of Anthelmintic Extract of Pomegranate (Punica granatum L) Against Ascaris suum Females In Vitro (Efek Anthelmintik Ekstrak Buah Delima (Punica granatum L) Terhadap Ascaris suum Betina Secara In Vitro). Bandung: Fakultas Kedokteran Universitas Kristen Maranata; 2017.

6. Himawan VB, Endharti AT, Rahayu ID. Antihelmintic Test of Papaya Leaf Decoction (Carica papaya L.) against Ascaris suum by In Vitro (Uji Daya Antihelmintik Dekok Daun Pepaya (Carica papaya L.) terhadap Ascaris suum secara In Vitro). Majalah Kesehatan FKUB. 2015;2(1):1-7.

7. Ulya N, Endharti AT, Setyohadi R. Uji Daya Anthelmintik Ekstrak Etanol Daun Kumis Kucing (Orthoshipon anistatus) Sebagai Anthelmintik Terhadap Ascaris suum Secara In Vitro. Majalah Kesehatan FK UB. 2014;130-136.

8. Pratama RH. The Influence of Avocado (Persea americana Mill.) Leaf Infusion on the Time of Death of Ascaris suum, Goeze (Pengaruh Infusa Daun Alpukat (Persea americana Mill.) Terhadap Waktu Kematian Cacing Ascaris suum, Goeze). Surakarta: FK UNS; 2010.

9. Miratunisa N, Asmara IY, Prihatina LM. The Relationship Between helminthiasis infection with nutritional status in elementary school students of SDN 27 Mataram (Hubungan Antara Infeksi Kecacingan Dengan Status Gizi Pada Murid Sekolah Dasar SDN 27 Mataram). 2017:1-9.

10. Maharani I. The Influence of Wuluh Starfruit Leaf (Averrhoa bilimbi) Infusion on Ascaris suum Mortality, Goeze In Vitro (Pengaruh Pemberian Infusum Daun Belimbing Wuluh (Averrhoa bilimbi) Terhadap Mortalitas Ascaris suum, Goeze Secara In Vitro). Surakarta: FKUNS; 2010. 
11. Mia ZR. The ultrastructural morphology of A.suum and A. lumbricoides worm eggs by the scanning electron microscope (SEM) method. Laboratory Explorative Research (Morfologi ultrastruktur telur cacing A. suum dan A. lumbricoides dengan metode scaning electron microscope (SEM). Penelitian Eksploratif Laboratoris). Surabaya: Universitas Airlangga; 2015.

12. Masduqi AF, Anggoro A. Utilization of Wuluh Starfruit Leaf Extract as a Toothpaste Formula (Pemamfaatan Ekstrak Daun Belimbing Wuluh Sebagai Formula Pasta Gigi). Media Farmasi. 2017;12021210.

13. Kristianto A. Effect of Tanin Rough Extract from Wuluh Starfruit Leaf (Averrhoa bilimbi) on Water Management (Pengaruh Ekstrak Kasar Tanin dari Daun Belimbing wuluh (Averrhoa bilimbi) pada Pengelolaan Air). Jember: FMIPA-UNEJ; 2013.

14. Ramadhan AG, Susanto, Wardatun S. Optimization of the Search for Content of Flavonoid Compounds in Wuluh Starfruit Leaves (Averrhoa bilimbi L) with the Simplex Lattice Design Method (Optimasi Penyari Terhadap Kadar Senyawa Flavonoid Daun Belimbing Wuluh (Averrhoa bilimbi L) dengan Metode Simplex Lattice Design). E-Journal Program Studi Farmasi (FMIPA) UNPAK-BOGOR. 2011;1-6.

15. Syahid MA. Effect of Putri Shame (Mimosa pudica) Extracts on Mortality in Ascaris suum by In Vitro (Pengaruh Ekstrak Putri Malu (Mimosa pudica) Terhadap Mortalitas Ascaris suum Secara In Vitro. 2011:9(2). 